\title{
Induction and Suppression of PEN3 Focal Accumulation During Pseudomonas syringae pv. tomato DC3000 Infection of Arabidopsis
}

\author{
Xiu-Fang Xin, ${ }^{1,2}$ Kinya Nomura, ${ }^{2}$ William Underwood, ${ }^{3}$ and Sheng Yang $\mathrm{He}^{1,2,4}$ \\ ${ }^{1}$ Department of Plant Biology, Michigan State University, East Lansing 48824, U.S.A.; ${ }^{2}$ Department of Energy Plant \\ Research Laboratory, Michigan State University, East Lansing; ${ }^{3}$ Energy Biosciences Institute, University of California, \\ Berkeley 94720, U.S.A.; ${ }^{4}$ Howard Hughes Medical Institute-Gordon and Betty Moore Foundation, Michigan State University, \\ East Lansing
}

Submitted 13 November 2012. Accepted 2 April 2013.

\begin{abstract}
The pleiotropic drug resistance $(\mathrm{PDR})$ proteins belong to the super-family of ATP-binding cassette (ABC) transporters. AtPDR8, also called PEN3, is required for penetration resistance of Arabidopsis to nonadapted powdery mildew fungi. During fungal infection, plasma-membrane-localized PEN3 is concentrated at fungal entry sites, as part of the plant's focal immune response. Here, we show that the pen3 mutant is compromised in resistance to the bacterial pathogen Pseudomonas syringae pv. tomato DC3000. $P$. syringae pv. tomato $\mathrm{DC} 3000$ infection or treatment with a flagellin-derived peptide, flg22, induced strong focal accumulation of PEN3-green fluorescent protein. Interestingly, after an initial induction of PEN3 accumulation, $P$. syringae $\mathrm{pv}$. tomato DC3000 but not the type-III-secretion-deficient mutant $h r c C$ could suppress PEN3 accumulation. Moreover, transgenic overexpression of the $P$. syringae pv. tomato DC3000 effector AvrPto was sufficient to suppress PEN3 focal accumulation in response to flg22. Analyses of $P$. $s y$ ringae pv. tomato DC3000 effector deletion mutants showed that individual effectors, including AvrPto, appear to be insufficient to suppress PEN3 accumulation when delivered by bacteria, suggesting a requirement for a combined action of multiple effectors. Collectively, our results indicate that $P E N 3$ plays a positive role in plant resistance to a bacterial pathogen and show that focal accumulation of PEN3 protein may be a useful cellular response marker for the Arabidopsis-P. syringae interaction.
\end{abstract}

The ATP-binding cassette (ABC) transporters, found in all organisms, represent one of the largest protein families known, with approximately 130 members in Arabidopsis thaliana (Jasinski et al. 2003). Based on phylogeny and structural features, this protein family is classified into several subfamilies, among which the three best-characterized ones are the multidrug resistance, pleiotropic drug resistance (PDR), and multidrug resistance-associated protein (Crouzet et al. 2006; Jasinski et al. 2003). ABC transporters are predicted to transport a broad

Corresponding author: S. Y. He; Telephone: +1.517.353.9181; E-mail: hes@msu.edu

*The $\boldsymbol{e}$-Xtra logo stands for "electronic extra" and indicates that six supplementary figures are published online.

(C) 2013 The American Phytopathological Society range of substrates, including toxic compounds, secondary metabolites, inorganic acid, or drugs (Martinoia et al. 2002; Verrier et al. 2008).

Thus far, the PDR subfamily has been found only in plants and fungi but not in animals. They are full-size ABC transporters, consisting of two hydrophobic (trans-membrane domain) and two hydrophilic (nucleotide-binding) domains (Crouzet et al. 2006). A few members of the PDR family in plants have been characterized. For example, earlier studies showed that a PDR protein, SpTUR2, from the plant Spirodela polyrrhiza is induced by the plant hormone abscisic acid (ABA) and environmental stress, and could transport sclareol (Smart and Fleming 1996; van den Brûle et al. 2002). NpPDR1 from Nicotiana plumbaginifolia was found to be important for pathogen resistance; NpPDR1-silenced plants show increased susceptibility to fungal and oomycete pathogens (Bultreys et al. 2009; Stukkens et al. 2005). The wheat gene Lr34, which encodes a putative PDR protein, confers durable resistance to leaf rust, stripe rust, and powdery mildew pathogens in wheat (Krattinger et al. 2009).

In Arabidopsis, there are 15 PDR genes. AtPDR 12, for example, is regulated by plant defense signaling, contributes to lead resistance, and, more recently, has been shown to transport ABA (Campbell et al. 2003; Kang et al. 2010; Lee et al. 2005). AtPDR8 has been reported to function in transport of heavy metal cadmium and auxin precursor indole-3-butyric acid (IBA) (Kim et al. 2007; Strader and Bartel 2009). In a study to identify Arabidopsis genes required for fungal penetration resistance, pdr8 (i.e., pen3) mutants were found to allow higher penetration rates of the nonhost powdery mildew fungus Blumeria graminis $f$. sp. hordei on Arabidopsis leaves (Stein et al. 2006). The pen3/pdr8 mutants are also defective in resistance to several other nonadapted pathogens, including Plectospaerella cucumerina, Erysiphe pisi (pea powdery mildew), and Phytophthora infestans (potato late blight) (Stein et al. 2006). Furthermore, PEN3-green fluorescent protein (GFP) was found to accumulate strongly at penetration sites during powdery mildew infection, and is hypothesized to focally transport defense-related compounds to prevent fungal hyphae growth as a plant defense mechanism (Stein et al. 2006).

PEN3 is also required for focal deposition of defense-associated callose in response to the microbe-associated molecular pattern (MAMP) flg22, suggesting a potentially positive role of PEN3 in plant resistance to bacterial pathogens (Bednarek et al. 2009; Clay et al. 2009). Surprisingly, however, Kobae and colleagues (2006) reported that the pen 3 mutant exhibits 
elevated basal defense against Pseudomonas syringae pv. tomato DC3000 under their growth conditions. It is not clear whether the resistance observed is caused directly by PEN3 acting as a genuine negative regulator of defense or by a secondary, nonspecific effect of the pen 3 mutation under certain growth conditions. In a study to examine a possible involvement of Arabidopsis PEN genes in resistance to $P$. syringae pv. tomato DC3000, we found that the pen3 mutant is compromised in resistance to $P$. syringae pv. tomato DC3000. Furthermore, PEN3-GFP protein focally accumulates in response to bacteria or flg22 and, interestingly, this focal accumulation is suppressed by $P$. syringae pv. tomato DC3000 in a type III secretion system-dependent manner. Our study affirms a positive role of PEN3 in plant resistance to a bacterial pathogen, and suggests that focal accumulation of PEN3 may be a useful cellular marker for the study of $P$. syringae pv. tomato DC3000 pathogenesis in Arabidopsis.

\section{RESULTS}

\section{$P E N 3$ is involved in plant resistance}

to $P$. syringae pv. tomato $\mathrm{DC} 3000$ infection.

Intrigued by the earlier publications of somewhat contradicting observations in terms of the role of PEN3 in plant response to bacteria or bacterial elicitor flg22 (Clay et al. 2009; Kobae et al. 2006), we examined the response of pen3-1, which is a lossof-function mutant (Stein et al. 2006), to infection by wild-type
P. syringae pv. tomato DC3000; the $\Delta \mathrm{CEL}$ mutant, a low-virulence mutant in which several conserved effector genes are deleted (Alfano et al. 2000; DebRoy et al. 2004); and the $h r c C$ mutant, which is defective in type III secretion (Yuan and $\mathrm{He}$ 1996). Col-0 and pen3 mutant plants were dip inoculated with bacteria at $1 \times 10^{8} \mathrm{CFU} / \mathrm{ml}$ and disease symptoms and bacterial numbers were evaluated 4 days later. Compared with Col-0 plants, pen3 mutant plants showed a higher susceptibility to $\triangle \mathrm{CEL}$ and $h r c C$ bacteria (Fig. 1A; Supplementary Fig. S1). $P$. syringae pv. tomato DC3000 multiplied to either a slightly higher level in pen3 mutant plants than in Col-0 plants (Fig. 1A) or similarly in pen 3 and Col-0 plants (Fig. 1B) but never to a lower level in pen 3 mutant plants compared with Col-0 plants, as was previously observed by Kobae and colleagues (2006).

\section{$P E N 3$ is required}

for flg22- and benzothiadiazole-induced plant protection against $P$. syringae pv. tomato $\mathrm{DC} 3000$ infection.

Flg22 and benzothiadiazole (BTH) are well-known inducers of MAMP-triggered immunity and salicylic acid (SA)-triggered immunity, respectively (Boller and Felix 2009; Vlot et al. 2009). We tested whether the pen 3 mutant is compromised in flg22- and BTH-triggered immunity against $P$. syringae pv. tomato DC3000 infection. Col-0 and pen3 plants were pretreated with $1 \mu \mathrm{M}$ flg22, $30 \mu \mathrm{M}$ BTH, or $\mathrm{H}_{2} \mathrm{O} ; 24 \mathrm{~h}$ later, plants were dip inoculated with $P$. syringae pv. tomato DC3000 at $1 \times 10^{8} \mathrm{CFU} / \mathrm{ml}$ and bacteria were enumerated 3 days after
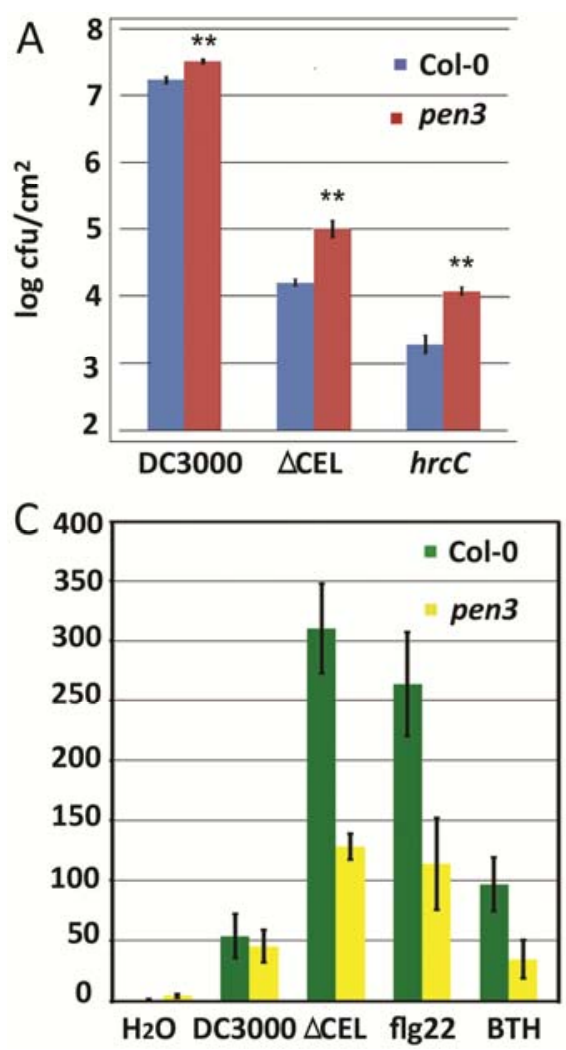

B

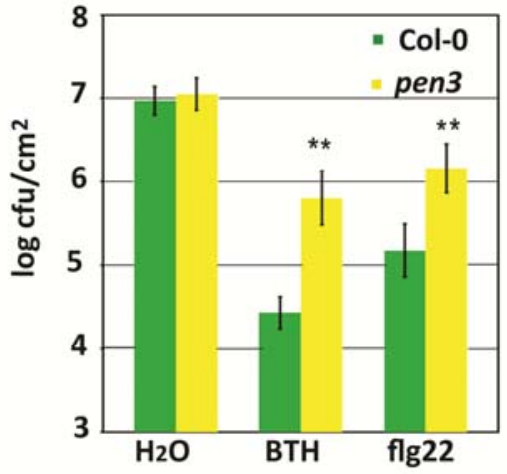

D

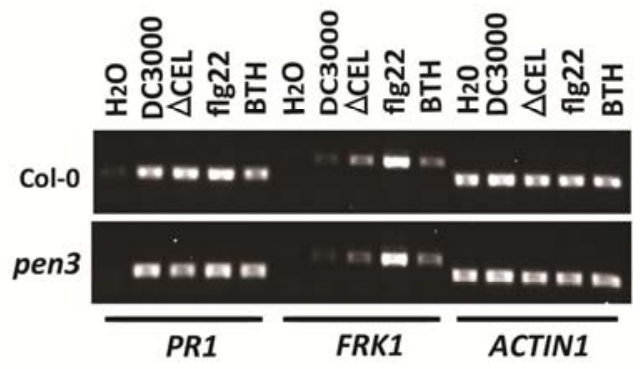

Fig. 1. PEN3 has a positive role in plant immunity against Pseudomonas syringae pv. tomato DC3000. A, The pen3-1 mutant is more susceptible to bacterial infection, compared with Col-0 plants. Plants were dip inoculated with wild-type $P$. syringae pv. tomato DC 3000 , the $\Delta$ CEL mutant, or the hrcC mutant at 1 $\times 10^{8} \mathrm{CFU} / \mathrm{ml}$ and bacteria were enumerated 4 days after inoculation; * and $* *$ indicate $P<0.05$ and 0.005 , respectively (two-tailed $t$ test for comparisons of Col-0 and pen 3 mutant plants). B, The pen 3 mutants are compromised in flg22- and benzothiadiazole (BTH)-induced immunity against $P$. syringae pv. tomato DC3000. $\mathrm{H}_{2} \mathrm{O}, 30 \mu \mathrm{M} \mathrm{BTH}$, or $1 \mu \mathrm{M}$ flg22 were sprayed onto plants $24 \mathrm{~h}$ before dip inoculation with P. syringae pv. tomato DC 3000 at $1 \times 10^{8}$ $\mathrm{CFU} / \mathrm{ml}$. Bacteria in infected plants were enumerated 3 days after inoculation. C, Callose deposition is reduced in pen 3 mutant plants. $\mathrm{H}_{2} \mathrm{O}$, P. syringae pv. tomato DC3000 $\left(1 \times 10^{8} \mathrm{CFU} / \mathrm{ml}\right)$, the $\Delta \mathrm{CEL}$ mutant $\left(1 \times 10^{8} \mathrm{CFU} / \mathrm{ml}\right), 1 \mu \mathrm{M}$ flg22, or $30 \mu \mathrm{M}$ BTH was hand-infiltrated into leaves. Callose deposits were counted $15 \mathrm{~h}$ after treatment. D, Reverse-transcriptase polymerase chain reaction (RT-PCR) shows that the transcript levels of $P R 1$ and FRK1 are not compromised in the pen 3 mutant in response to bacterial infection or flg22 or BTH treatment. $\mathrm{H}_{2} \mathrm{O}$, P. syringae pv. tomato $\mathrm{DC} 3000\left(1 \times 10^{8} \mathrm{CFU} / \mathrm{ml}\right)$, the $\Delta \mathrm{CEL}$ mutant $\left(1 \times 10^{8} \mathrm{CFU} / \mathrm{ml}\right), 1 \mu \mathrm{M}$ flg22, or $30 \mu \mathrm{M} \mathrm{BTH}$ was infiltrated into Arabidopsis leaves. Then, $15 \mathrm{~h}$ later, leaves were collected for RNA extraction and subjected to RT-PCR analysis. The ACTIN1 gene was used as a constitutively expressed gene control. 
inoculation. As expected, $P$. syringae pv. tomato DC3000 grew much less in Col-0 plants after flg22 or BTH treatment. However, P. syringae pv. tomato DC3000 grew to a much higher level in pen 3 plants compared with Col-0 plants, demonstrating that PEN3 is required for flg22- and BTH-induced immunity against $P$. syringae pv. tomato DC3000 (Fig. 1B).

Callose deposition is a common downstream defense response, which can be triggered by bacterial infection or flg22 or BTH treatment (Clay et al. 2009; Hauck et al. 2003). To determine the role of PEN3 in callose deposition, we infiltrated pen3 and Col-0 plant leaves with water, $P$. syringae pv. tomato DC3000 $\left(1 \times 10^{8} \mathrm{CFU} / \mathrm{ml}\right)$, the $\triangle \mathrm{CEL}$ mutant $\left(1 \times 10^{8} \mathrm{CFU} / \mathrm{ml}\right)$, $1 \mu \mathrm{M}$ flg22, or $30 \mu \mathrm{M} \mathrm{BTH}$, and callose deposits were counted $15 \mathrm{~h}$ later. Callose deposition was significantly decreased in the pen3 mutant in response to the $\triangle$ CEL mutant, flg22, and BTH treatment, whereas $P$. syringae pv. tomato DC3000 suppressed callose deposition in both plants (Fig. 1C).

To determine whether PEN3 is required for defense gene induction, we examined the expression levels of FRK1 and PRI, which are commonly used marker genes for flg22- and SA-triggered immunity, respectively (Boudsocq et al. 2010; Spoel and Dong 2012). Water, $P$. syringae pv. tomato DC3000 $\left(1 \times 10^{8}\right.$ $\mathrm{CFU} / \mathrm{ml})$, the $\triangle \mathrm{CEL}$ mutant $\left(1 \times 10^{8} \mathrm{CFU} / \mathrm{ml}\right), 1 \mu \mathrm{M}$ flg22, or $30 \mu \mathrm{M}$ BTH was infiltrated into plant leaves, and RNA was collected and subjected to reverse-transcriptase polymerase chain reaction (RT-PCR) to examine the transcript level of $P R l$ and FRK1. PRI and FRK1 expression was induced by every treatment except water (Fig. 1D). However, neither $P R 1$ nor $F R K 1$ showed differential expression in response to different bacteria or flg22 or BTH treatment in the pen 3 mutant versus in Col-0 plants, suggesting that $P R 1$ and FRK1 expression is not affected in the pen 3 mutant, despite the compromised plant immunity in this mutant.

\section{PEN3 protein forms strong focal accumulation} in response to flg22 treatment.

PEN3 protein was shown to accumulate at fungal penetration sites (Stein et al. 2006). We examined whether PEN3 focal accumulation also occurs in plants infiltrated with flg22. The transgenic Arabidopsis expressing pPEN3:PEN3-GFP (in the pen3-1 background) (Stein et al. 2006) was infiltrated with 100 $\mathrm{nM}$ flg22 or water (used as control). Confocal microscopy was performed $6 \mathrm{~h}$ later to determine the localization pattern of

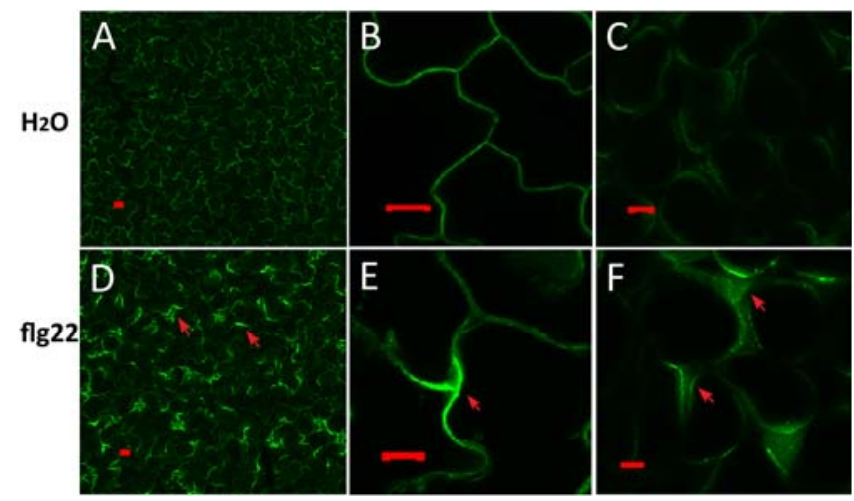

Fig. 2. Treatment with flg22 induces strong focal accumulation of PEN3GFP protein. A to $\mathbf{C}$, Confocal laser scanning microscopy using transgenic Arabidopsis expressing PEN3-GFP shows that PEN3-GFP has a uniform plasma-membrane localization pattern at the resting state $\left(\mathrm{H}_{2} \mathrm{O}\right.$ treated). A and B, epidermal cells; C, mesophyll cells. D to F, PEN3-GFP forms strong focal accumulation (indicated by arrows) in response to $100 \mathrm{nM}$ flg22. The flg22 was hand infiltrated into PEN3-GFP leaves and images were collected $6 \mathrm{~h}$ later. Focal accumulation formed in both E, epidermal cells and $\mathbf{F}$, mesophyll cells; $\mathbf{D}$, a large-area view shows PEN3-GFP foci in epidermal cells. Images shown here are z-stacks. Bars $=10 \mu \mathrm{m}$.

PEN3-GFP. Water-treated plants displayed a uniform pattern of PEN3-GFP in the plasma-membrane (PM) (Fig. 2A to C), consistent with earlier reports (Kobae et al. 2006; Stein et al. 2006). In contrast, flg22 treatment triggered strong focal accumulation of PEN3-GFP, evidenced by distinct, strong signal foci (Fig. 2D to F, arrows). The strong focal accumulation can be visualized in both epidermal cells (Fig. 2E) and mesophyll cells (Fig. 2F). We also examined the localization of another plant PM protein, AUX1-yellow fluorescent protein (YFP) (an auxin influx facilitator fused to YFP) (Bennett et al. 1996), in response to $h r c C$ bacteria. AUX1-YFP did not form focal accumulation, suggesting that not all PM proteins form focal accumulation in response to bacteria (Supplementary Fig. S2).

Next, we used a Heteractis crispa red fluorescent protein (hcRed)-labeled $h r c C$ strain to determine whether the PEN3 focal accumulation sites are associated with the presence of bacteria. Indeed, hcRed-labeled $h r c C$ bacteria were found at or near PEN3-GFP accumulation sites (Supplementary Fig. S3), suggesting that the locations of bacteria or locally concentrated pathogen-associated molecular patterns define whether PEN3 focal accumulation occurs.

\section{$P$. syringae pv. tomato DC3000 induces focal accumulation of PEN3-GFP, but only transiently.}

We next examined possible focal accumulation of PEN3GFP in the context of bacterial infection. $P$. syringae pv. tomato DC3000 and $h r c C$ bacteria (at $1 \times 10^{8} \mathrm{CFU} / \mathrm{ml}$ ) were infiltrated into PEN3-GFP plant leaves, which were subsequently observed under a confocal microscope at various time points. At early time points, both $P$. syringae pv. tomato DC3000 and $h r c C$ induced focal accumulation of PEN3-GFP, with strong signals observed consistently at $5 \mathrm{~h}$ after infiltration (Fig. 3A and B). The strong focal accumulation of PEN3GFP persisted in $h r c C$ mutant-infiltrated leaves; however, in

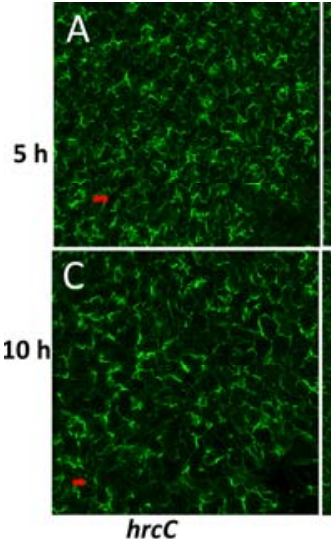

hrcC

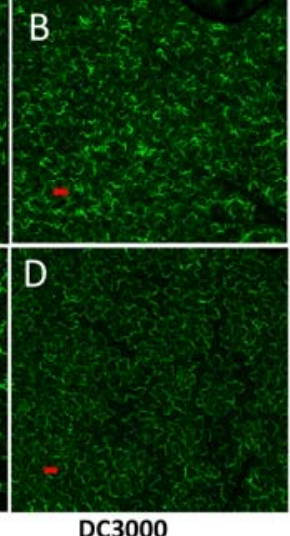

DC3000

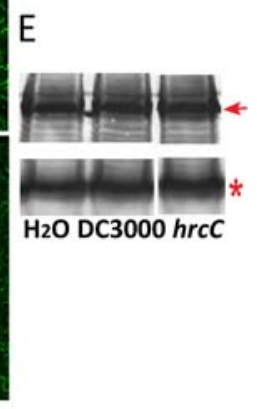

Fig. 3. Dynamic changes of PEN3 focal accumulation in response to Pseudomonas syringae pv. tomato DC3000 infection. A to D, Cellular localization of PEN3-GFP responds to $P$. syringae pv. tomato DC3000 and the hrcC mutant differently. P. syringae pv. tomato DC3000 and hrcC bacteria were hand infiltrated into PEN3-GFP leaves at $1 \times 10^{8} \mathrm{CFU} / \mathrm{ml}$. A and $\mathbf{B}$, At $5 \mathrm{~h}$ after infiltration, strong focal accumulation of PEN3-GFP signal was observed in leaves infiltrated with either bacterial strain. $\mathbf{C}$ and D, However, 10 h after infiltration, $P$. syringae pv. tomato DC3000 suppressed PEN3-GFP focal accumulation, whereas the $h r c C$ mutant did not. Bars $=20 \mu \mathrm{m}$. E, Total protein levels of PEN3-GFP are not changed in response to infiltration with $\mathrm{H}_{2} \mathrm{O}$ or $P$. syringae pv. tomato DC3000. $\mathrm{H}_{2} \mathrm{O}, P$. syringae pv. tomato DC3000, or $\mathrm{hrcC}$ (at $1 \times 10^{8} \mathrm{CFU} / \mathrm{ml}$ ) was hand-infiltrated and $0.3 \mathrm{~g}$ of leaf tissue was collected for each treatment $10 \mathrm{~h}$ after infiltration. Total membrane was collected by ultracentrifuge at $100,000 \times g$, and subjected to immunoblot analysis with a green fluorescent protein (GFP) antibody (Abcam). Arrow shows the PEN3-GFP band with a predicted size of $180 \mathrm{kDa}$. Asterisk shows a nonspecific band from the same gel, indicating equal protein loading. Lanes were cropped from the same blot with uniform adjustment of brightness and contrast. 
$P$. syringae pv. tomato DC3000-treated leaves, accumulation of PEN3-GFP began to disappear after $7 \mathrm{~h}$ and, by $10 \mathrm{~h}$ after infiltration, almost no focal accumulation could be observed (Fig. 3C and D). The transient focal accumulation pattern of PEN3-GFP during $P$. syringae pv. tomato DC3000 infection but not $h r c C$ mutant infection provides the first evidence that P. syringae pv. tomato DC3000 is able to suppress PEN3 focal accumulation in a type III secretion-dependent manner. Although we used high inocula $\left(1 \times 10^{8} \mathrm{CFU} / \mathrm{ml}\right)$ to minimize population differences between DC3000 and the hrcC mutant, we still observed that the population of the $\operatorname{rrc} C$ mutant was approximately 10 -fold lower than that of $P$. syringae pv. tomato DC3000 at $10 \mathrm{~h}$ after infiltration (Supplementary Fig. S4). To determine whether the lack of suppression of PEN3 focal accumulation by the $h r c C$ mutant at $10 \mathrm{~h}$ after infiltration was caused by the lower population level, we adjusted $h r c C$ inocula accordingly (at $1 \times 10^{9} \mathrm{CFU} / \mathrm{ml}$ ). However, even at a 10 -fold higher inoculum (compared with that of $P$. syringae pv. tomato DC3000), the $h r c C$ mutant still could not suppress PEN3 focal accumulation, suggesting that high $P$. syringae pv. tomato DC3000 population per se does not account for the ability of $P$. syringae pv. tomato DC3000 to suppress PEN3 focal accumulation.

To further evaluate changes in PEN3-GFP focal accumulation, the protein level of PEN3-GFP was checked. PEN3-GFP plant leaves were infiltrated with water, $P$. syringae pv. tomato DC3000, or $h r c C$ bacteria (at $1 \times 10^{8} \mathrm{CFU} / \mathrm{ml}$ ) and leaf tissues were collected $10 \mathrm{~h}$ later. Total microsomal fraction was isolated and PEN3-GFP protein level was checked by Western blot. A protein band with predicted size for PEN3-GFP (approximately $180 \mathrm{kDa}$ ) was detected by anti-GFP antibody with similar intensity among different samples (Fig. 3E; Supplementary Fig. S5), suggesting that the suppression of PEN3 focal accumulation observed in $P$. syringae pv. tomato DC3000 was not due to a decreased amount of PEN3-GFP but, rather, to a change in the pattern of PEN3-GFP localization in the PM.

PEN3 focal accumulation can be suppressed by the effector AvrPto overexpressed in transgenic Arabidopsis.

Because we found that flg22 strongly induced focal accumulation of PEN-GFP (Fig. 2D to F) and because $P$. syringae pv. tomato DC3000 effector AvrPto has been known to interfere with the function of the flagellin/flg22 receptor FLS2 (Göhre et al. 2008; Xiang et al. 2008), we examined the possibility that AvrPto might be able to suppress the focal accumulation of PEN3-GFP. We first used transgenically expressed AvrPto to address this question. AvrPto transgenic plants
(Hauck et al. 2003) were crossed with PEN3-GFP plants and T1 plants were obtained. AvrPto expression was induced by spraying plants with $30 \mu \mathrm{M}$ dexamethasone (DEX). Then, $24 \mathrm{~h}$ later, $1 \mu \mathrm{M}$ flg22 was infiltrated, and the PEN3-GFP pattern was examined $6 \mathrm{~h}$ after flg22 infiltration. Although flg22 induced strong focal accumulation in water-treated AvrPto/ PEN3-GFP plants (Fig. 4) or DEX-treated PEN3-GFP plants (Supplementary Fig. S6), greatly reduced focal accumulation of PEN3-GFP was observed in DEX-treated AvrPto/PEN3GFP plants. This result showed that transgenic overexpression of a single effector, AvrPto, is sufficient to reduce flg22induced focal accumulation of PEN3-GFP.

Next, we investigated whether AvrPto could suppress focal accumulation of PEN3-GFP when delivered by $P$. syringae pv. tomato DC3000 during infection. For this purpose, we used a $P$. syringae pv. tomato DC3000 effector deletion mutant, CUCPB5500, in which 18 clustered effector genes were deleted, leaving only 10 nonclustered effector genes, including avrPto, in the genome (Kvitko et al. 2009). However, we found that this mutant strain induced strong focal accumulation of PEN3-GFP (Table 1) in a manner that was similar to the $h r c C$ mutant, suggesting that none of these 10 effectors, including AvrPto, was sufficient to suppress focal accumulation of PEN3-GFP during infection.
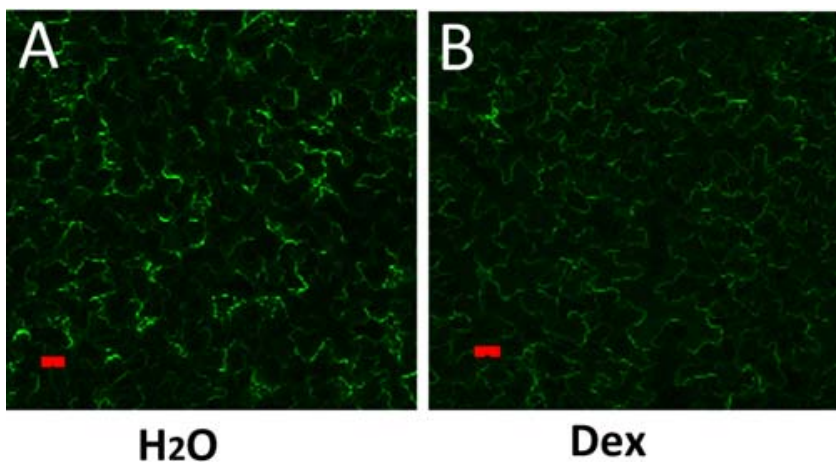

Fig. 4. Overexpression of Pseudomonas syringae pv. tomato DC3000 effector AvrPto in transgenic Arabidopsis suppresses PEN3 focal accumulation. Water or dexamethasone (DEX) $(30 \mu \mathrm{M})$ was sprayed onto AvrPto/PEN3 GFP plants to induce AvrPto expression. Then, 24 h later, 1 $\mu \mathrm{M}$ flg22 was infiltrated into leaves. Confocal images were collected $6 \mathrm{~h}$ after flg22 infiltration. Bar $=20 \mu \mathrm{m}$. A, AvrPto/PEN3-GFP plants treated with water were used as control. Strong focal accumulation of PEN3-GFP was observed after flg22 treatment. B, DEX-induced AvrPto overexpression suppressed PEN3 focal accumulation.

Table 1. Different abilities of Pseudomonas syringae pv. tomato DC3000 mutant strains to suppress PEN3-GFP focal accumulation

\begin{tabular}{|c|c|c|}
\hline Strains (references) & Effectors genes deleted in the strain & $\begin{array}{c}\text { Degree of } \\
\text { PEN3 focal } \\
\text { accumulation }^{a}\end{array}$ \\
\hline hrcC (Yuan and He 1996) & Type III secretion system deficient & +++ \\
\hline $\begin{array}{l}\text { CUCPB5500 (Cunnac et al. 2011; } \\
\text { Kvitko et al. 2009) }\end{array}$ & $\begin{array}{l}\text { hорАA1-1; hopAA1-2; hopAO1; hopAM1-2; hopC1; hopD1; avrE; hopF2; hopG1; } \\
\text { hopH1; hopM1; hopN1; hopO1-1; hopQ1-1; hopR1; hopT1-1; hopU1; hopV1; HopX1 }\end{array}$ & +++ \\
\hline CUCPB5539 (Kvitko et al. 2009) & $\begin{array}{l}\text { hopAA1-1; hopAA1-2; hopAO1; hopC1; hopD1; avrE; hopG1; hopH1; hopM1; hopN1; } \\
\text { hopQ1-1; hopR1; hopV1 }\end{array}$ & +++ \\
\hline $\begin{array}{l}\text { CUCPB5459 (Cunnac et al. 2011; } \\
\text { Kvitko et al. 2009) }\end{array}$ & $\begin{array}{l}\text { hорAA1-2; hopAO1; hopAM1-2; hopC1; hopD1; hopF2; hopG1; hopH1; hopO1-1; } \\
\text { hopQ1-1; hopR1; hopT1-1; hopU1; hopV1; HopX1 }\end{array}$ & +++ \\
\hline $\begin{array}{l}\text { CUCPB5452 (Kvitko et al. 2009; } \\
\text { Wei et al. 2007) }\end{array}$ & $\begin{array}{l}\text { hopAA1-2; hopAO1; hopAM1-2; hopC1; hopD1; hopG1; hopH1; hopO1-1; hopQ1-1; } \\
\text { hopR1; hopT1-1; hopV1; HopX1 }\end{array}$ & ++ \\
\hline CUCPB5451 (Wei et al. 2007) & hopAA1-2; hopAO1; hopC1; hopD1; hopG1; hopH1; hopQ1-1; hopR1; hopV1; & + \\
\hline$\Delta$ CEL (Alfano et al. 2000; DebRoy et al. 2004) & HopAA1-1; avrE; hopM1; hopN1 & + \\
\hline CUCPB5448 (Wei et al. 2007) & hopC1; hopD1; hopH1; hopQ1-1; hopR1 & - \\
\hline CUCPB5138 (Buell et al. 2003; Wei et al. 2007) & hopAM1-2; hopO1-1; hopT1-1; HopX1; (pDC3000A-B-) & - \\
\hline CUCPB5445 (Wei et al. 2007) & hopC1; hopH1 & - \\
\hline DC3000 (Ma et al. 1991) & $\ldots$ & - \\
\hline
\end{tabular}

a Average number of focal accumulation sites per $1.6 \mathrm{~mm}^{2}(1.26$ by $\left.1.26 \mathrm{~mm})\right):+++=>70,++=40-70,+=6-40$, and $-=<5$. 


\section{Analysis of $P$. syringae pv. tomato DC3000 effector deletion mutants in their ability to suppress PEN3 focal accumulation.}

We next examined additional $P$. syringae pv. tomato DC300 effector deletion mutants in their ability to suppress PEN3 focal accumulation (Table 1). These strains contained different combinations of clustered effector gene deletions and showed differential virulence on Arabidopsis or N. benthamiana (Buell et al. 2003; Kvitko et al. 2009; Wei et al. 2007). Bacteria strains were infiltrated into PEN3-GFP leaves at $1 \times 10^{8} \mathrm{CFU} /$ $\mathrm{ml}$ and images were collected $10 \mathrm{~h}$ later. Average number of PEN3-GFP focal accumulation sites per $1.6 \mathrm{~mm}^{2}(1.26$ by 1.26 $\mathrm{mm}$ ) was counted for each strain. We found that these strains possess different abilities of suppressing PEN3-GFP focal accumulation (Table 1). However, this analysis also showed that there is not a specific effector or cluster that is capable of suppressing PEN3-GFP focal accumulation in the context of bacterial infection. For example, whereas CUCPB5448 effectively suppressed PEN3-GFP focal localization, CUCPB5452 could not. This initial result suggested to us that effector clusters $\mathrm{I}$ (containing hopU1 and hopF2) and X (containing hopAM1-2, hopX1, hopO1-1, and hopT1-1) would be responsible for the suppression. However, CUCPB 5539, which contains only effector clusters I and X, failed to suppress PEN3 accumulation. Thus, a yet-to-be discovered combination of type III effectors is needed to suppress PEN3-GFP focal accumulation during $P$. syringae pv. tomato DC3000 infection.

\section{DISCUSSION}

In this study, we reevaluated the role of PDR8/PEN3 in plant interaction with a bacterial pathogen. Contrary to what was observed by Kobae and colleagues (2006), we found that Arabidopsis pdr8/pen 3 mutants are compromised in resistance to $P$. syringae pv. tomato DC3000, with the most obvious defect observed in flg22 and BTH protection assays or when $P$. syringae pv. tomato DC3000 mutants with reduced virulence (e.g., the $h r c C$ or $\Delta$ CEL mutant) are used in disease assays. Furthermore, we found that, similar to powdery mildew fungal infection, $P$. syringae pv. tomato DC3000 infection and bacterial MAMP (flg22) treatment efficiently induced strong focal accumulation of PEN3-GFP protein, suggesting that this focal localization pattern of PEN3 is a common defense response to fungal and bacterial pathogens. Furthermore, we found that PEN3 focal accumulation is suppressed by $P$. syringae pv. tomato DC3000 in a type III secretion-dependent manner. The immune defects displayed in pen 3 mutants and dynamic changes of PEN3 focal accumulation during $P$. syringae pv. tomato DC3000 infection are consistent with and extend the initial observation by Clay and colleagues (2009) that PEN3 has a positive role in mediating defense-associated callose deposition in response to a bacterial MAMP flg22.

The different results with respect to responses of pen $3 \mathrm{mu}-$ tants to $P$. syringae pv. tomato DC3000 infection obtained by us and by Kobae and colleagues (2006) warrant some further discussion. Kobae and colleagues found that the pdr8 T-DNA insertion mutant exhibited chlorotic lesions and hypersensitiveresponse-like cell death under their laboratory growth conditions, and that $P$. syringae pv. tomato DC3000 growth was suppressed in this mutant. However, under our growth condition, we did not observe these phenotypes with the pen $3-1$ mutant. The plants looked healthy and were often slightly larger than Col-0 control plants. We speculate that pdr8/pen3 plants may be more sensitive than Col-0 plants to abiotic or biotic stresses associated with certain growth conditions. When stressed, pdr8/pen3 plants may activate nonspecific, secondary defense, which could lead to "gain-of-function" resistance to $P$. syringae pv. tomato
DC3000. Indeed, Stein and associates (2006) reported that pen3 mutant plants have heightened sensitivity to abiotic stress, such as high light, and Kobae and colleagues found that $p d r 8$ mutants grown under nonsterile conditions showed constitutively expressed defense genes, such as $P R-1, P R-2$, and AtrbohD. Plants grown under our condition did not have elevated expression of defense-related genes, such as $P R-1$ and $F R K 1$ (Fig. 1D). Therefore, obtaining healthy pdr8/pen 3 plants is critical to reveal the enhanced disease susceptibility and avoid stressinduced secondary effects. Interestingly, the effect of plant growth conditions on disease phenotypes is not unique to pdr8/pen 3 mutations and has been shown for other Arabidopsis defense-associated mutations ( $\mathrm{Lu}$ et al. 2010; Nomura et al. 2011; Veronese et al. 2006). Another reason that might contribute to the disparity of the pen 3 plant responses to $P$. syringae pv. tomato DC3000 is the different bacterial inoculation methods used. We dip inoculated plants with bacteria, and Kobae and colleagues used infiltration. PEN3 expression was shown to be enriched in cells near stomata (Kobae et al. 2006). Therefore, it is possible that PEN3 may have an important defense function at the site of bacterial entry, which would be revealed only by the dip inoculation.

How PEN3 contributes to plant resistance to $P$. syringae pv. tomato DC3000 remains to be determined. Knowledge of the substrates of the PEN3 transporter will be an essential step toward understanding its function. It seems reasonable to hypothesize that PEN3, being a member of the PDR family of transporters, may transport different classes of substrates when plants are exposed to different abiotic or biotic stresses. PDR in yeast have been shown to transport a variety of compounds with little or no common features (Bauer et al. 1999; Rogers et al. 2001). PEN3 has been reported to extrude cadmium, contributing to heavy metal resistance, and to mediate the export of auxin precursor IBA (Kim et al. 2007; Strader and Bartel 2009). However, it is not yet clear how cadmium and IBA export would influence $P$. syringae pv. tomato DC3000 pathogenesis. PEN3 is also required for callose deposition (Clay et al. 2009), although it is not known how callose deposition alone could restrict bacterial multiplication. Therefore, it remains possible that PEN3 may also transport antimicrobial compounds effective against bacterial pathogens (Lipka et al. 2005; Stein et al. 2006). How PEN3's different transport activities are regulated and coordinated should be an interesting topic of future study.

Focal cellular accumulation of plant defense-associated proteins has emerged as a common theme during fungal infection. Multiple plant proteins have been demonstrated to be redistributed at fungal entry sites. These proteins include PEN1, VAMP721/VAMP722, PEN2, and PEN3 in Arabidopsis and barley syntaxin ROR2 and mildew resistance locus O (MLO) (Bhat et al. 2005; Kwon et al. 2008; Lipka et al. 2005; Stein et al. 2006). The mechanisms underlying the redistribution of these proteins are not yet clear. Studies on Arabidopsis PEN1 have led to the hypothesis that attempted entry of fungal hyphae triggers formation of specific PM microdomains, to which certain PM proteins, including PEN1, are recruited. The focal nature of PEN1-dependent exocytosis could lead to localized cell-wall defense responses, such as papillae formation, which requires the ARF-GTP exchange factor GNOM (Bhat et al. 2005; Meyer et al. 2009; Nielsen et al. 2012). It would be important for future research to examine the possibility of PEN3 being recruited to PM microdomains or other membrane structures, such as exosomes, in response to flg22 and bacteria. Equally important would be to identify $P$. syringae pv. tomato DC3000 effectors that suppress focal accumulation of PEN3-GFP. Although we have shown that transgenically expressed AvrPto could reduce flg22-induced PEN3 focal accumulation, consistent with the ability of this effector to inhibit the function of the flagellin/ 
flg22 receptor FLS2 (Göhre et al. 2008; Xiang et al. 2008), we have, thus far, failed to identify individual effectors (or combinations of effectors) that could block PEN3-GFP focal accumulation in the context of $P$. syringae pv. tomato DC3000 infection. Likely, this is because transgenic expression of AvrPto produced a much higher level of AvrPto protein than that delivered by bacteria during infection. It is also possible that bacteria release a more complex mix of elicitors (compared with flg22 alone) that trigger PEN3-GFP focal accumulation, which requires a more complicated mix of effectors to suppress. We believe that identifying these effectors and studying their suppression mechanisms may provide a powerful means of understanding the general mechanism of focal accumulation of PEN3 and, possibly, other defense proteins. Even without such understanding, however, we believe that the dynamic change of PEN3 localization pattern, as revealed in this study, can be used as a facile cellular maker for study of Arabidopsis-P. syringae interactions in live cells.

\section{MATERIALS AND METHODS}

\section{Plant materials and growth conditions.}

The following $A$. thaliana mutants and transgenic plants were used. The pen3-1 mutant and PEN3:PEN3-GFP transgenic Arabidopsis plants were described by Stein and associates (2006). AvrPto transgenic Arabidopsis plants were described by Hauck and associates (2003). All plants are in Col-0 background. Seed were sown in Redi-earth soil and kept at $4^{\circ} \mathrm{C}$ for 2 days for stratification. Plants were grown with $12 \mathrm{~h}$ of light (80 to $100 \mu \mathrm{E} \mathrm{m}^{-2} \mathrm{~s}^{-1}$ ). Five-week-old plants were used for disease assays and confocal microscopy.

\section{Bacterial infection assay.}

Plants were grown to 5 weeks old and dip inoculated with P. syringae pv. tomato DC3000 strains at $1 \times 10^{8} \mathrm{CFU} / \mathrm{ml}$. Infected plants were monitored for a 3 - to 4-day period, and bacterial populations were determined at day 3 or 4 . For flg22 and BTH protection assays, plants were sprayed with $\mathrm{H}_{2} \mathrm{O}, 30 \mu \mathrm{M}$ $\mathrm{BTH}$, or $1 \mu \mathrm{M}$ flg22 $24 \mathrm{~h}$ before dip inoculation with $P$. syringae pv. tomato DC3000 $\left(1 \times 10^{8} \mathrm{CFU} / \mathrm{ml}\right)$.

\section{Callose staining.}

Callose staining was performed $15 \mathrm{~h}$ after bacteria $\left(1 \times 10^{8}\right.$ $\mathrm{CFU} / \mathrm{ml}$ ) or flg22 or BTH infiltration. Staining was done as described previously (Nomura et al. 2011). Averages of values are presented with standard deviations derived from at least four independent leaves for each treatment.

\section{Microsome isolation and protein immunoblot.}

Plant leaves were infiltrated with bacteria at $1 \times 10^{8} \mathrm{CFU} / \mathrm{ml}$ and collected $10 \mathrm{~h}$ later. After polytron homogenization, samples were centrifuged at $13,000 \times g$ for $15 \mathrm{~min}$ at $4{ }^{\circ} \mathrm{C}$. The supernatant was collected and subjected to centrifugation at $100,000 \times g$ for $40 \mathrm{~min}$ at $4^{\circ} \mathrm{C}$ to collect the microsomal fraction.

For immunoblot analysis of PEN3-GFP protein, a microsomal pellet was resuspended in sodium dodecyl sulfate polyacrylamide gel electrophoresis (SDS-PAGE) sample buffer and heated at $50^{\circ} \mathrm{C}$ for $5 \mathrm{~min}$. Proteins were subjected to SDSPAGE separation and transferring onto membrane (Immobilon-P membrane; Millipore Corp., Bedford, MA, U.S.A.). An anti-GFP antibody (rabbit polyclonal; Abcam, Cambridge, U.K.) was used for detecting PEN3-GFP.

\section{Laser-scanning microscopy.}

PEN3-GFP or AvrPto/PEN3-GFP plants were grown to 5 weeks old and fully expanded leaves were infiltrated with bacteria, flg22, or $\mathrm{H}_{2} \mathrm{O}$. At different time points after treatment, infiltrated leaves were randomly picked for confocal imaging.
Imaging was performed with an Olympus FluoView FV1000 Laser-Scanning Confocal Microscope for GFP visualization at $488 \mathrm{~nm}$. Imaging experiments were conducted with a $\times 40$ oil immersion objective (Fig. 2A, C, and D) or a $\times 10$ dry objective (Figs. 2B and E, 3, 4, and 5). Images were processed using Olympus Fluoview Viewer software, version 2.0B.

\section{Quantification of PEN3 focal accumulation sites.}

Confocal images (1.26 by $1.26 \mathrm{~mm}$ ) were collected randomly from plant leaves inoculated with each strain. Focal accumulation sites were counted on each image. Six representative images were analyzed for each strain to obtain the average. At least two experimental repeats were performed for each strain.

\section{RT-PCR analysis of gene expression.}

Arabidopsis leaves were infiltrated with $\mathrm{H}_{2} \mathrm{O}$, bacteria at $1 \times$ $10^{8} \mathrm{CFU} / \mathrm{ml}, 1 \mu \mathrm{M}$ flg22, or $30 \mu \mathrm{M}$ BTH and used for RT-PCR analysis. Leaf samples were collected $15 \mathrm{~h}$ after infiltration. Total RNA was purified by using the RNAgents Total RNA Isolation System (Promega Corp., Madison, WI, U.S.A.), followed by RT-PCR using the TaKaRa RNA PCR Kit (ver. 3.1; Takara, Tokyo). The following primers were used: $P R 1$, forward primer 5'ATGAATTTTACTGGCTATTCTCGA3' and reverse primer 5'CAAACTCCATTGCACGTGTTCGCA3'; $F R K 1$, forward primer 5'TCCAAGCGAAGATGGCGGACTT CG3' and reverse primer 5'CTACCTTGCTCGAGGAACCAT CTC3'; and ACTIN1, forward primer 5'ATGGCTGATGGTGA AGACATTCAA3' and reverse primer 5'TTAGCTTTCGGGTT AAGCGGTGCC $3^{\prime}$.

\section{ACKNOWLEDGMENTS}

We thank S. Somerville at University of California, Berkeley, for providing pen3-1 mutant and PEN3-GFP transgenic seed; M. Frame at the Center for Advanced Microscopy at Michigan State University for advice on microscopy; and E. Morey for editing of the manuscript. This work was supported by grants from NIH (R01AI068718 for financial support of K. Nomura and F32-GM0834393 for W. Underwood.), DOE (the Chemical Sciences, Geosciences, and Biosciences Division, Office of Basic Energy Sciences, Office of Science DE-FG02-91ER20021; graduate assistantship to X.-F. Xin), and Gordon and Betty Moore Foundation to S. Y. He. X.-F. Xin, K. Nomura, and S. Y. He initiated the project and designed experiments. X.-F. Xin, K. Nomura, and W. Underwood conducted the experiments. X.-F. Xin, K. Nomura, W. Underwood, and S. Y. He critically evaluated and analyzed data. X.-F. Xin and S. Y. He wrote the manuscript with input from all authors.

\section{LITERATURE CITED}

Alfano, J. R., Charkowski, A. O., Deng, W. L., Badel, J. L., PetnickiOcwieja, T., van Dijk, K., and Collmer, A. 2000. The Pseudomonas syringae Hrp pathogenicity island has a tripartite mosaic structure composed of a cluster of type III secretion genes bounded by exchangeable effector and conserved effector loci that contribute to parasitic fitness and pathogenicity in plants. Proc. Natl. Acad. Sci. U.S.A. 97:4856-4861.

Bauer, B. E., Wolfger, H., and Kuchler, K. 1999. Inventory and function of yeast ABC proteins: About sex, stress, pleiotropic drug and heavy metal resistance. Biochim. Biophys. Acta 1461:217-236.

Bednarek, P., Pislewska-Bednarek, M., Svatos, A., Schneider, B., Doubsky, J., Mansurova, M., Humphry, M., Consonni, C., Panstruga, R., Sanchez-Vallet, A., Molina, A., and Schulze-Lefert, P. 2009. A glucosinolate metabolism pathway in living plant cells mediates broadspectrum antifungal defense. Science 323:101-106.

Bennett, M. J., Marchant, A., Green, H. G., May, S. T., Ward, S. P., Millner, P. A., Walker AR, Schulz B, Feldmann KA. 1996. Arabidopsis AUX1 gene: A permease-like regulator of root gravitropism. Science 273:948950.

Bhat, R. A., Miklis, M., Schmelzer, E., Schulze-Lefert, P., and Panstruga, R. 2005. Recruitment and interaction dynamics of plant penetration resistance components in a plasma membrane microdomain. Proc. Natl. Acad. Sci. U.S.A. 102:3135-3140.

Boller, T., and Felix, G. 2009. A renaissance of elicitors: Perception of 
microbe-associated molecular patterns and danger signals by patternrecognition receptors. Annu. Rev. Plant Biol. 60:379-406.

Boudsocq, M., Willmann, M. R., McCormack, M., Lee, H., Shan, L., He, P., Bush, J., Cheng, S. H., and Sheen, J. 2010. Differential innate immune signalling via $\mathrm{Ca}(2+)$ sensor protein kinases. Nature 464:418-422.

Buell, C. R., Joardar, V., Lindeberg, M., Selengut, J., Paulsen, I. T., Gwinn, M. L., Dodson, R. J., Deboy, R. T., Durkin, A. S., Kolonay, J. F., Madupu, R., Daugherty, S., Brinkac, L., Beanan, M. J., Haft, D. H., Nelson, W. C., Davidsen, T., Zafar, N., Zhou, L., Liu, J., Yuan, Q. Khouri, H., Fedorova, N., Tran, B., Russell, D., Berry, K., Utterback, T., Van Aken, S. E., Feldblyum, T. V., D’Ascenzo, M., Deng, W. L. Ramos, A. R., Alfano, J. R., Cartinhour, S., Chatterjee, A. K., Delaney, T. P., Lazarowitz, S. G., Martin, G. B., Schneider, D. J., Tang, X., Bender, C. L., White, O., Fraser, C. M., and Collmer, A. 2003. The complete genome sequence of the Arabidopsis and tomato pathogen Pseudomonas syringae pv. tomato DC3000. Proc. Natl. Acad. Sci. U.S.A. 100:10181-10186.

Bultreys, A., Trombik, T., Drozak, A., and Boutry, M. 2009. Nicotiana plumbaginifolia plants silenced for the ATP-binding cassette transporter gene NpPDR 1 show increased susceptibility to a group of fungal and oomycete pathogens. Mol. Plant Pathol. 10:651-663.

Campbell, E. J., Schenk, P. M., Kazan, K., Penninckx, I. A., Anderson, J. P., Maclean, D. J., Cammue, B. P., Ebert, P. R., and Manners, J. M. 2003. Pathogen-responsive expression of a putative ATP-binding cassette transporter gene conferring resistance to the diterpenoid sclareol is regulated by multiple defense signaling pathways in Arabidopsis. Plant Physiol. 133:1272-1284.

Clay, N. K., Adio, A. M., Denoux, C., Jander, G., and Ausubel, F. M. 2009. Glucosinolate metabolites required for an Arabidopsis innate immune response. Science 323:95-101.

Crouzet, J., Trombik, T., Fraysse, A. S., and Boutry, M. 2006. Organization and function of the plant pleiotropic drug resistance $\mathrm{ABC}$ transporter family. FEBS (Fed. Eur. Biochem. Soc.) Lett. 580:1123-1130.

Cunnac, S., Chakravarthy, S., Kvitko, B. H., Russell, A. B., Martin, G. B., and Collmer, A. 2011. Genetic disassembly and combinatorial reassembly identify a minimal functional repertoire of type III effectors in Pseudomonas syringae. Proc. Natl. Acad. Sci. U.S.A. 108:2975-2980.

DebRoy, S., Thilmony, R., Kwack, Y. B., Nomura, K., and He, S. Y. 2004. A family of conserved bacterial effectors inhibits salicylic acid-mediated basal immunity and promotes disease necrosis in plants. Proc. Natl. Acad. Sci. U.S.A. 101:9927-9932.

Göhre, V., Spallek, T., Häweker, H., Mersmann, S., Mentzel, T., Boller, T. de Torres, M., Mansfield, J. W., and Robatzek, S. 2008. Plant patternrecognition receptor FLS2 is directed for degradation by the bacterial ubiquitin ligase AvrPtoB. Curr. Biol. 18:1824-1832.

Hauck, P., Thilmony, R., and He, S. Y. 2003. A Pseudomonas syringae type III effector suppresses cell wall-based extracellular defense in susceptible Arabidopsis plants. Proc. Natl. Acad. Sci. U.S.A. 100:85778582

Jasinski, M., Ducos, E., Martinoia, E., and Boutry, M. 2003. The ATPbinding cassette transporters: Structure, function, and gene family comparison between rice and Arabidopsis. Plant Physiol. 131:1169-1177.

Kang, J., Hwang, J. U., Lee, M., Kim, Y. Y., Assmann, S. M., Martinoia, E., and Lee, Y. 2010. PDR-type ABC transporter mediates cellular uptake of the phytohormone abscisic acid. Proc. Natl. Acad. Sci. U.S.A. 107:2355-2360

Kim, D. Y., Bovet, L., Maeshima, M., Martinoia, E., and Lee, Y. 2007. The ABC transporter AtPDR8 is a cadmium extrusion pump conferring heavy metal resistance. Plant J. 50:207-218.

Kobae, Y., Sekino, T., Yoshioka, H., Nakagawa, T., Martinoia, E., and Maeshima, M. 2006. Loss of AtPDR8, a plasma membrane ABC transporter of Arabidopsis thaliana, causes hypersensitive cell death upon pathogen infection. Plant Cell Physiol. 47:309-318.

Krattinger, S. G., Lagudah, E. S., Spielmeyer, W., Singh, R. P., HuertaEspino, J., McFadden, H., Bossolini, E., Selter, L. L., and Keller, B. 2009. A putative $A B C$ transporter confers durable resistance to multiple fungal pathogens in wheat. Science 323:1360-1363.

Kvitko, B. H., Park, D. H., Velásquez, A. C., Wei, C. F., Russell, A. B., Martin, G. B., Schneider, D. J., and Collmer, A. 2009. Deletions in the repertoire of Pseudomonas syringae pv. tomato DC3000 type III secretion effector genes reveal functional overlap among effectors. PLoS Pathog. 5:e1000388. Published online.

Kwon, C., Neu, C., Pajonk, S., Yun, H. S., Lipka, U., Humphry, M., Bau, S., Straus, M., Kwaaitaal, M., Rampelt, H., El Kasmi, F., Jürgens, G., Parker, J., Panstruga, R., Lipka, V., and Schulze-Lefert, P. 2008. Co-option of a default secretory pathway for plant immune responses. Nature 451:835-840
Lee, M., Lee, K., Lee, J., Noh, E. W., and Lee, Y. 2005. AtPDR12 contributes to lead resistance in Arabidopsis. Plant Physiol. 138:827-836.

Lipka, V., Dittgen, J., Bednarek, P., Bhat, R., Wiermer, M., Stein, M., Landtag, J., Brandt, W., Rosahl, S., Scheel, D., Llorente, F., Molina, A., Parker, J., Somerville, S., and Schulze-Lefert, P. 2005. Pre- and postinvasion defenses both contribute to nonhost resistance in Arabidopsis. Science 310:1180-1183.

Lu, D., Wu, S., Gao, X., Zhang, Y., Shan, L., and He, P. 2010. A receptorlike cytoplasmic kinase, BIK1, associates with a flagellin receptor complex to initiate plant innate immunity. Proc. Natl. Acad. Sci. U.S.A. 107:496-501.

Ma, S. W., Morris, V. L., and Cuppels, D. A. 1991. Characterization of a DNA region required for production of the phytotoxin coronatine by Pseudomonas syringae pv. tomato. Mol. Plant-Microbe Interact. 4:69-77.

Martinoia, E., Klein, M., Geisler, M., Bovet, L., Forestier, C., Kolukisaoglu, U., Muller-Rober, B., and Schulz, B. 2002. Multi-functionality of plant ABC transporters-more than just detoxifiers. Planta 214:345-355.

Meyer, D., Pajonk, S., Micali, C., O’Connell, R., and Schulze-Lefert, P. 2009. Extracellular transport and integration of plant secretory proteins into pathogen-induced cell wall compartments. Plant J. 57:986-999.

Nielsen, M. E., Feechan, A., Böhlenius, H., Ueda, T., and ThordalChristensen, H. 2012. Arabidopsis ARF-GTP exchange factor, GNOM, mediates transport required for innate immunity and focal accumulation of syntaxin PEN1. Proc. Natl. Acad. Sci. U.S.A. 109:11443-11448.

Nomura, K., Mecey, C., Lee, Y. N., Imboden, L. A., Chang, J. H., and He, S. Y. 2011. Effector-triggered immunity blocks pathogen degradation of an immunity-associated vesicle traffic regulator in Arabidopsis. Proc. Natl. Acad. Sci. U.S.A. 108:10774-10779.

Rogers, B., Decottignies, A., Kolaczkowski, M., Carvajal, E., Balzi, E. and Goffeau, A. 2001. The pleitropic drug ABC transporters from Saccharomyces cerevisiae. J. Mol. Microbiol. Biotechnol. 3:207-214.

Smart, C. C., and Fleming, A. J. 1996. Hormonal and environmental regulation of a plant PDR5-like ABC transporter. J. Biol. Chem. 271:1935119357.

Spoel, S. H., and Dong, X. 2012. How do plants achieve immunity? Defence without specialized immune cells. Nat. Rev. Immunol. 12:89-100.

Stein, M., Dittgen, J., Sánchez-Rodríguez, C., Hou, B. H., Molina, A., Schulze-Lefert, P., Lipka, V., and Somerville, S. 2006. Arabidopsis PEN3/PDR8, an ATP binding cassette transporter, contributes to nonhost resistance to inappropriate pathogens that enter by direct penetration. Plant Cell 18:731-746.

Strader, L. C., and Bartel, B. 2009. The Arabidopsis PLEIOTROPIC DRUG RESISTANCE8/ABCG36 ATP binding cassette transporter modulates sensitivity to the auxin precursor indole-3-butyric acid. Plant Cell 21:1992-2007.

Stukkens, Y., Bultreys, A., Grec, S., Trombik, T., Vanham, D., and Boutry, M. 2005. NpPDR1, a pleiotropic drug resistance-type ATP-binding cassette transporter from Nicotiana plumbaginifolia, plays a major role in plant pathogen defense. Plant Physiol. 139:341-352.

van den Brûle, S., Müller, A., Fleming, A. J., and Smart, C. C. 2002. The $\mathrm{ABC}$ transporter SpTUR2 confers resistance to the antifungal diterpene sclareol. Plant J. 30:649-662.

Verrier, P. J., Bird, D., Burla, B., Dassa, E., Forestier, C., Geisler, M., Klein, M., Kolukisaoglu, U., Lee, Y., Martinoia, E., Murphy, A., Rea, P. A., Samuels, L., Schulz, B., Spalding, E. J., Yazaki, K., and Theodoulou, F. L. 2008. Plant ABC proteins-a unified nomenclature and updated inventory. Trends Plant Sci. 13:151-159.

Veronese, P., Nakagami, H., Bluhm, B., Abuqamar, S., Chen, X., Salmeron, J., Dietrich, R. A., Hirt, H., and Mengiste, T. 2006. The membrane-anchored BOTRYTIS-INDUCED KINASE1 plays distinct roles in Arabidopsis resistance to necrotrophic and biotrophic pathogens. Plant Cell 18:257-273.

Vlot, A. C., Dempsey, D. A., and Klessig, D. F. 2009. Salicylic Acid, a multifaceted hormone to combat disease. Annu. Rev. Phytopathol. 47:177-206.

Wei, C. F., Kvitko, B. H., Shimizu, R., Crabill, E., Alfano, J. R., Lin, N. C. Martin, G. B., Huang, H. C., and Collmer, A. 2007. A Pseudomonas syringae pv. tomato DC3000 mutant lacking the type III effector HopQ11 is able to cause disease in the model plant Nicotiana benthamiana. Plant J. 51:32-46.

Xiang, T., Zong, N., Zou, Y., Wu, Y., Zhang, J., Xing, W., Li, Y., Tang, X., Zhu, L., Chai, J., and Zhou, J. M. 2008. Pseudomonas syringae effector AvrPto blocks innate immunity by targeting receptor kinases. Curr. Biol. 18:74-80.

Yuan, J., and He, S. Y. 1996. The Pseudomonas syringae Hrp regulation and secretion system controls the production and secretion of multiple extracellular proteins. J. Bacteriol. 178:6399-6402. 